\title{
What Have We Learned about Fiscal Policy from the Crisis?*
}

\author{
David Romer \\ University of California, Berkeley \\ IMF Conference on Macro and Growth Policies in the Wake of the Crisis \\ March 2011 \\ This version: September 2011
}

Forthcoming in Olivier J. Blanchard, David Romer, A. Michael Spence, and Joseph E. Stiglitz, eds., In the Wake of the Crisis: Leading Economists Speak Out (Cambridge: MIT Press)

The financial and macroeconomic crisis that began in 2008 has shattered some of the core beliefs of macroeconomists and macroeconomic policymakers:

- We thought we had macroeconomic fluctuations well under control, but they are back with a vengeance.

- We thought that the zero lower bound on nominal interest rates was a minor issue, but it has proven central to the behavior of the macroeconomy.

- We had not paid much attention to issues of financial regulation and financial disruptions, but they too have turned out to be critical to macroeconomic performance.

- The idea that policymakers would to tolerate years of exceptionally high unemployment due to a deficiency of aggregate demand has gone from unthinkable five years ago to fact today.

\footnotetext{
* I am grateful to Christina Romer for helpful comments. The views expressed are purely my own.
} 
- The workhorse new Keynesian dynamic stochastic general equilibrium (DSGE) models on which we were concentrating so much of our attention have been of minimal value in addressing the greatest macroeconomic crisis in three-quarters of a century.

In short, we have a lot of reflection to do. In this chapter, I focus on four lessons about fiscal policy that I think can be learned from the crisis. ${ }^{1}$

Lesson 1: We need fiscal tools for short-run stabilization. The first lesson is straightforward: we need fiscal tools for short-run stabilization. Before the crisis, there was broad agreement among macroeconomists and policymakers that short-run stabilization was almost exclusively the province of monetary policy. Monetary policy is more flexible, more easily insulated from political pressures, and more easily placed in the hands of independent experts. We thought that the zero lower bound would bind infrequently and not sharply_-and that in the unlikely event that it did bind sharply, monetary policymakers had other tools to use in place of reductions in the policy interest rate. ${ }^{2}$

We now know that this view was wrong. We suffered shocks larger than what almost anyone thought was within the realm of reasonable possibility. The constraint imposed by the zero lower bound turned out to be huge (for example, Rudebusch 2009). And central banks did

\footnotetext{
${ }^{1}$ My claim about DSGE models is not directly about fiscal policy and so is not covered in this chapter, but it may require some elaboration. I am not asserting that modern macroeconomics in general has not been valuable. To give just one example, empirical and theoretical work on credit-market imperfections (for example, Bernanke 1983; Bernanke and Gertler 1989; and Kiyotaki and Moore 1997) offers important insights into financial crises and very likely informed the policy response. However, the real-time performance of the models that represented the precrisis state of the art of the new Keynesian DSGE research program was dismal (Edge and Gürkaynak 2010). And most insights from the extensions of those models in response to the crisis arise more transparently in models that dispense with much of the new Keynesian DSGE superstructure. Caballero (2010) provides a broad critique of the workhorse models.

${ }^{2}$ Reifschneider and Williams (2000) provide a representative example of an analysis suggesting the likely unimportance of the zero lower bound. Eggertsson and Woodford (2003) and Svensson (2003) discuss alternative tools. Bernanke (2000, 2002) argues forcefully that even in the presence of the zero lower bound, monetary policy could be relied on to prevent deflation — and, by extension, an extended period of abnormally low inflation and weak real performance.
} 
not use tools other than the policy rate on a scale even remotely close to large enough to make up for the loss of stimulus caused by the zero lower bound.

Perhaps the lack of aggressiveness in using those tools reflects an understanding of the costs of using them that has eluded conventional analyses. But central bankers have yet to provide evidence of such costs. A more likely possibility is that the culture of central banking makes it much easier to take unusual steps when the financial system is at risk than when the threat is "merely" years of exceptionally high unemployment. But regardless of the reason, monetary policy was not used aggressively enough to prevent very large demand shortfalls.

Countries needed other tools, and the alternative to monetary tools is fiscal ones. For that reason, almost every major country adopted substantial discretionary fiscal stimulus in the crisis (U.S. Council of Economic Advisers 2009). Since there could be another major demand shortfall in the future, it follows that instruments of discretionary fiscal stimulus are needed as part of the macroeconomic toolkit.

Lesson 2: We have even stronger evidence that fiscal policy is effective than we did before the crisis. In a major crisis, the demand shortfall is likely to be large and long-lasting. Moreover, the possibilities for policies that shift intertemporal incentives are limited. As a result, much of discretionary fiscal stimulus is likely to take largely conventional forms, such as broadbased income tax cuts, increased transfers, and higher government purchases. The second lesson is that the evidence that has come out of the crisis has made it even clearer that such conventional fiscal actions stimulate the macroeconomy.

As Robert Solow has noted, we should not be trying to find the multiplier: the effects of fiscal policy are highly regime dependent. One critical issue is the monetary regime. Consider estimating the effects of fiscal policy over the period from, say, 1985 to 2005. Central banks 
were actively trying to offset other forces affecting the economy, and they had the tools to do so. If they were successful, the estimated effects of fiscal policy would be close to zero. But this tells us nothing about the effects of fiscal policy in situations where monetary policymakers are unable or unwilling to offset other forces.

Fortunately, the crisis has sparked a great deal of work on the short-run effects of fiscal policy, much of it focusing on settings where monetary policy does not respond aggressively. Some of it uses evidence from the crisis itself, but much does not; some focuses on a particular country, usually the United States, but some uses larger samples; and a considerable body of the work looks at evidence from different regions within a country, again usually the United States. One particularly appealing aspect of this last set of studies is that because monetary policy is conducted at the national level, it is inherently being held constant when one is looking at withincountry variation.

Collectively, this research points very strongly (although not unanimously) to the conclusion that when monetary policy does not respond, conventional fiscal stimulus is quite effective. ${ }^{3}$ And a careful examination of the evidence gives no support to the view that when monetary policy is constrained, fiscal contractions are expansionary (International Monetary Fund 2010).

Even so, I find even more compelling two types of evidence that predate the crisis. The first comes from wars. The major increases in government purchases in the two world wars and

\footnotetext{
${ }^{3}$ For within-country evidence, see Chodorow-Reich, Feiveson, Liscow, and Woolston (2011); Suárez Serrato and Wingender (2011); Shoag (2010); Fishback and Kachanovskaya (2010); and Nakamura and Steinsson (2011). For cross-country evidence, see International Monetary Fund (2010), U.S. Council of Economic Advisers (2009), and Kraay (2011). For time-series evidence (as well as simulation-based evidence), see Hall (2009), Barro and Redlick (2011), Fisher and Peters (2010), Coenen et al. (2010), and Christiano, Eichenbaum, and Rebelo (2011). On this list, all but Kraay, Barro and Redlick, and Fisher and Peters implicitly or explicitly try to provide evidence about the case where monetary policy does not act to offset the effects of fiscal policy. With the exception of two of these three, all the papers suggest substantial effects of fiscal policy (the two exceptions are Kraay and Barro and Redlick, which suggest moderate effects). As I describe below, this brief tour omits all work that predates the crisis.
} 
the Korean War were associated with booms in economic activity, and those booms occurred despite very large tax increases and extensive microeconomic interventions whose purpose was to restrict private demand. These outcomes appear to be overwhelming evidence that fiscal stimulus matters.

The other type of evidence is more general evidence about the functioning of the macroeconomy. We know that monetary policy has powerful real effects (which means that aggregate demand matters), that current disposable income is important to consumption, and that cash flow and sales have strong effects on investment. ${ }^{4}$ It would take a strange combination of circumstances for those things to be true but for fiscal policy, which one would expect to work through those channels, not to be effective.

Given this wide range of evidence-not to mention the large body of precrisis work on the effects of fiscal policy that I have not touched on-I think we should view the question of whether fiscal stimulus is effective as settled.

Lesson 3: Fiscal space is valuable. The third lesson is that fiscal space is valuable. That is, being in a healthy fiscal situation is important to responding aggressively to a collapse of demand.

One way to see the value of fiscal space is by considering a thought experiment. Suppose that the United States or the countries of Europe had begun the crisis with a modest debt-to-GDP ratio, no looming entitlement problems, and confidence that policymakers would not let a temporary stimulus become permanent. It is hard to think of any strong force that would have prevented policymakers from enacting much more fiscal stimulus than they did. In the United

\footnotetext{
${ }^{4}$ The literature on departures from the permanent-income hypothesis is much too voluminous to summarize here. One important point is that much of the evidence of departures comes from countercyclical changes in taxes and similar interventions, and so is directly relevant to fiscal policy. One recent example is Parker, Souleles, Johnson, and McClelland (2011). My own summary of work cash flow and investment can be found in Romer (2012, 447451). For sales and investment, see, for example, Abel and Blanchard (1986).
} 
States, for example, there might have been a much larger personal tax cut, a large one-year or two-year payroll tax holiday, and perhaps twice as much relief for state and local governments. My guess is that the stimulus would have been closer to $\$ 1.5$ trillion than to the $\$ 0.8$ trillion that was actually enacted. The result would have been a milder downturn and a much faster recovery.

The other way to see the importance of fiscal space is to look at countries that had it. Without examining the evidence systematically, I am reluctant to draw firm conclusions. But China, Korea, and Australia, which have sound fiscal situations, undertook relatively large fiscal expansions even though they were not hit exceptionally hard by the downturn and still had considerable room to spare on monetary policy. And Iceland, which entered the crisis with little debt, undertook policies that raised its debt-to-GDP ratio by about 100 percentage points.

Thus, aggressive fiscal stimulus can greatly reduce the costs of a macroeconomic crisis, but lack of fiscal space can greatly constrain stimulus. It follows that having fiscal room to maneuver is valuable.

Lesson 4: Political-economy considerations are extremely important. The fourth and final lesson has a different character. It is that in understanding fiscal policy responses to the crisis, political-economy considerations are central.

It is not hard to describe some of the major features of the most appropriate fiscal response to the crisis. Very large short-run stimulus would have been coupled with the enactment of measures that yielded very large improvements in the long-run fiscal outlook over time. The timing of the actual long-run tightening would have been tied to monetary policy exit: only when monetary policymakers would otherwise have raised interest rates would the fiscal tightening begin. Some measures would have simultaneously addressed both the short-run and long-run problems. An example is phased-in increases in value-added taxes, which act like reductions in 
real interest rates and generate revenue over time. And policy would have been incremental: some measures would have been enacted in response to the beginnings of the crisis, and then they would have been expanded or contracted if the crisis proved more or less severe than expected.

This description does not fit actual policy well. With few exceptions, countries did not adopt substantial back-loaded fiscal contraction together with short-run stimulus. The scale of the stimulus was far less than what could have been done if it had been coupled with major longrun consolidation. Measures that simultaneously addressed short-run and long-run problems were rare. And the response to the fact that the crisis proved far worse than almost everyone originally thought was not to increase stimulus commensurately. Indeed, in many cases it was to cut back on stimulus.

The source of the large gap between actual policies and those I have described as most appropriate is not sophisticated analyses suggesting that the policies that have been pursued are better. Rather, the source is in the workings of political systems.

Both theory and evidence indicate that the reasons that the political process often leads to highly undesirable outcomes are not to be found in models of rational agents with sophisticated economic understandings who have the misfortune of being caught in games whose equilibria are highly inefficient. Rather, they are to be found in the simple fact that voters' incentives to understand difficult policy issues are minimal. As a result, they-understandably-rely on intuition, superficial impressions, and emotion in their political decisions (Caplan 2007; Romer 2003).

In the case of fiscal stimulus in response to a massive downturn, I think that economists grossly overestimated our success in conveying basic macroeconomic messages about the value 
of government budget deficits when private demand collapses. When the crisis came, those messages were swept away by voters' gut feeling that when ordinary people are suffering and have no choice but to cut back, then for the government to be profligate is not just unwise but morally offensive. Likewise, although there are large benefits to enacting policies that gradually address long-run budget problems, those benefits are not enough to overcome the barriers created by the fact that few citizens know much about the specifics of the long-run fiscal outlook, and so react negatively to concrete plans to cut spending or raise taxes relative to current policy—even though maintaining current policy is not feasible.

Where does this leave us? I think that these lessons leave struggling countries and concerned policymakers in pretty bad shape. We face both a severe short-run problem and a severe and closely related long-run one.

In the short run, the crisis is still going on. In the advanced economies, resource utilization remains deeply depressed relative to normal, with no prospect of rapid recovery. In the United States, the likelihood is a painfully slow return to normal; in much of Europe and in Japan, there are few signs of any return at all. Having a conference about "policies in the wake of the crisis" today strikes me as a little like having a conference on the lessons from the Great Depression in $1934 .{ }^{5}$ Now is not the time for a contemplative look back; it is time for redoubled efforts to figure out what can be done and to make it happen.

Sadly, the prospects do not appear good. It is still easy to characterize what should be done. In the advanced economies, there should be aggressive use of creative monetary policy, short-run fiscal stimulus, and measures to address the long-run fiscal problems. But the political environment is skeptical of monetary actions, hostile to fiscal stimulus, and only a shade more

\footnotetext{
${ }^{5}$ I was tempted to ask who chose the conference title until I remembered that I was one of the organizers. In our defense, it seemed like a better idea in 2009 than it does now.
} 
open to long-run fiscal consolidation than it usually is. Unfortunately, I do not have anything better to propose to economists than that we not resign ourselves to years of high unemployment when it is curable, and that we make the case over and over again for policies that will bring about improvement.

The related long-run problem is that we may face another crisis sometime in the next several decades. The Great Depression led to institutional changes—deposit insurance, financial regulation, and attention to stabilization policy—that made a recurrence less likely. Nothing as significant appears to be coming out of the current crisis. There has been some financial regulatory reform around the world, but how effective it will be is not yet clear. The political environment may make it harder in future crises to use the extraordinary monetary, financial, and fiscal tools that kept this crisis from spiraling completely out of control. And the crisis has worsened countries' long-run fiscal problems. This both reduces the fiscal space that would be available in the event of a future crisis and increases the chances that a crisis will start through a loss of confidence in countries' fiscal soundness.

Again, I see no easy solutions. Economists can continue to make the case for the value of the types of policies that were followed in the crisis. We can argue for reforms that will make the financial system more resilient. We can make the case for reforms that will strengthen the fiscal response to a crisis, such as automatic triggers for some types of fiscal policy changes and putting some aspects of discretionary fiscal policy in independent, expert hands. And we can explain the need for long-run consolidation.

I think we should make those arguments as frequently and as forcefully as possible. But I do not see deep grounds for optimism that we will be heard. 


\section{REFERENCES}

Abel, Andrew B., and Olivier J. Blanchard. 1986. “The Present Value of Profits and Cyclical Movements in Investment.” Econometrica 54 (March): 249-273.

Barro, Robert J., and Charles J. Redlick. 2011. "Macroeconomic Effects from Government Purchases and Taxes.” Quarterly Journal of Economics 126 (February): 51-102.

Bernanke, Ben S. 1983. "Nonmonetary Effects of the Financial Crisis in the Propagation of the Great Depression.” American Economic Review 73 (June): 257-276.

Bernanke, Ben S. 2000. “Japanese Monetary Policy: A Case of Self-Induced Paralysis?” In Japan's Financial Crisis and Its Parallels to U.S. Experience, ed. Ryoichi Mikitani and Adam S. Posen, 149-166. Washington, D.C.: Institute for International Economics.

Bernanke, Ben S. 2002. “Deflation: Making Sure 'It' Doesn't Happen Here.” Remarks before the National Economists Club, Washington, D.C. (November).

Bernanke, Ben S., and Mark Gertler. 1989. "Agency Costs, Net Worth, and Business Fluctuations.” American Economic Review 79 (March): 14-31.

Caballero, Ricardo J. 2010. "Macroeconomics after the Crisis: Time to Deal with the Pretenseof-Knowledge Syndrome.” Journal of Economic Perspectives 24 (Fall): 85-102.

Caplan, Bryan. 2007. The Myth of the Rational Voter: Why Democracies Choose Bad Policies. Princeton: Princeton University Press.

Chodorow-Reich, Gabriel, Laura Feiveson, Zachary Liscow, and William Gui Woolston. 2011. "Does State Fiscal Relief during Recessions Increase Employment? Evidence from the American Recovery and Reinvestment Act.” Unpublished paper (August).

Christiano, Lawrence, Martin Eichenbaum, and Sergio Rebelo. 2011. "When Is the Government Spending Multiplier Large?” Journal of Political Economy 119 (February): 78-121.

Coenen, Günter, et. al. 2010. "Effects of Fiscal Stimulus in Structural Models.” International Monetary Fund Working Paper WP/10/73 (March).

Edge, Rochelle M., and Refet S. Gürkaynak. 2010. "How Useful Are Estimated DSGE Model Forecasts for Central Bankers?” Brookings Papers on Economic Activity, no. 2, 209-244.

Eggertsson, Gauti, and Michael Woodford. 2003. "The Zero Bound on Interest Rates and Optimal Monetary Policy.” Brookings Papers on Economic Activity, no. 1, 139-233.

Fishback, Price V., and Valentina Kachanovskaya. 2010. “In Search of the Multiplier for Federal Spending in the States during the New Deal.” National Bureau of Economic Research Working Paper No. 16561 (November). 
Fisher, Jonas D. M., and Ryan Peters. 2010. "Using Stock Returns to Identify Government Spending Shocks.” Economic Journal 120 (May): 414-436.

Hall, Robert E. 2009. “By How Much Does GDP Rise If the Government Buys More Output?” Brookings Papers on Economic Activity, no. 2, 183-231.

International Monetary Fund. 2010. "Will It Hurt? Macroeconomic Effects of Fiscal Consolidation.” World Economic Outlook (October), Chapter 3. Washington, DC: International Monetary Fund.

Kiyotaki, Nobuhiro, and John Moore. 1997. “Credit Cycles.” Journal of Political Economy 105 (April): 211-248.

Kraay, Aart. 2011. "How Large Is the Government Spending Multiplier? Evidence from World Bank Lending.” Unpublished paper, World Bank (June). Quarterly Journal of Economics, forthcoming.

Nakamura, Emi, and Jón Steinsson. 2011. "Fiscal Stimulus in a Monetary Union: Evidence from U.S. Regions.” National Bureau of Economic Research Working Paper No. 17391 (September).

Parker, Jonathan A., Nicholas S. Souleles, David S. Johnson, and Robert McClelland. 2011. “Consumer Spending and the Economic Stimulus Payments of 2008.” National Bureau of Economic Research Working Paper No. 16684 (January).

Reifschneider, David L., and John C. Williams. 2000. "Three Lessons for Monetary Policy in a Low-Inflation Era.” Journal of Money, Credit, and Banking 32 (November, Part 2): 936966.

Romer, David. 2003. "Misconceptions and Political Outcomes." Economic Journal 113 (January): 1-20.

Romer, David. 2012. Advanced Macroeconomics. Fourth edition. New York: McGraw-Hill.

Rudebusch, Glenn D. 2009. "The Fed's Monetary Policy Response to the Current Crisis." Federal Reserve Bank of San Francisco Economic Letter No. 2009-17 (May).

Shoag, Daniel. 2010. "The Impact of Government Spending Shocks: Evidence on the Multiplier from State Pension Plan Returns.” Unpublished paper, Harvard University.

Suárez Serrato, Juan Carlos, and Philippe Wingender. 2011. "Estimating Local Fiscal Multipliers.” Unpublished paper, University of California, Berkeley (March).

Svensson, Lars E. O. 2003. "Escaping from a Liquidity Trap and Deflation: The Foolproof Way and Others." Journal of Economic Perspectives 17 (Fall): 145-166. 
U.S. Council of Economic Advisers. 2009. "The Effects of Fiscal Stimulus: A Cross-Country Perspective." September. 